\title{
The sexual behaviour of prenatally androgenized ewes observed in the field
}

\author{
I. J. Clarke* \\ M.R.C. Unit of Reproductive Biology, 2 Forrest Road, Edinburgh EH1 2QW, U.K.
}

\begin{abstract}
Summary. Pregnant ewes were implanted with $1 \mathrm{~g}$ testosterone between Days 30-80, $50-100,70-120$ or $90-140$ of gestation. Treatments which began on Days 30,50 or 70 resulted in the birth of androgenized females which failed to show regular oestrous cycles in adult life, but which exhibited patterns of male-like behaviour. This was most marked in the Day 50-100 and 70-120 groups, whereas complete masculinization of the external genitalia was confined to the Day 30-80 group. Animals in the Day 90-140 group had regular oestrous cycles although they showed slight enhancement of masculine behaviour compared to the control ewes.

These results demonstrate that androgenization involves both a suppression of female behavioural patterns, and the development of male patterns; these are not mutually exclusive.
\end{abstract}

\section{Introduction}

Masculine and feminine patterns of sexual behaviour are not mutually exclusive, and some male-like behaviour is common amongst females of most species (Beach, 1968). Female sheep, however, rarely show any male-like sexual behaviour; but if female sheep fetuses are exposed to testosterone from Days 20 or 60 of gestation until birth, they do not display oestrus during adulthood (defeminization) and show male-like mating patterns (masculinization) (Short, 1974). Studies of androgenized female dogs (Beach \& Kuehn, 1970; Beach, Kuehn, Sprague \& Anisko, 1972) have emphasized that a reduction in feminine behaviour may occur without a marked increase in masculine behaviour. Furthermore, androgenized female rats display enhanced masculine behaviour (Sodersten, 1973) but may also exhibit intense lordosis (Brown-Grant, 1975).

The purpose of the present investigation was to establish the spectrum of behaviour that could be produced by exposing female sheep fetuses to testosterone at different periods of fetal life, and to determine the extent that behaviour is dictated by the degree of masculinization of the reproductive tract.

\section{Materials and Methods}

\section{Animals}

Finnish Landrace $\times$ Dorset Horn ewes were mated to rams of the same breed, and subcutaneous implants of $1 \mathrm{~g}$ testosterone (Intervet Laboratories, Viking House, Bar Hill, Cambs) were given between Days 30 and $80(\mathrm{~N}=8), 50$ and $100(\mathrm{~N}=8), 70$ and $120(\mathrm{~N}=6)$ or 90 and $140(\mathrm{~N}=6)$ of pregnancy. A group of 8 untreated pregnant ewes served as controls. The lambs from the ewes treated on Days 30-80 (D30-80) and Days 50-100 (D50-100) and the untreated ewes were born in April 1974; those from ewes treated on Days 70-120 (D70-120) and Days 90-140 (D90-140) were born in February 1975. Normal male lambs were distinguished at birth by the presence of palpable testes in the scrotum. Androgenized female lambs showed various degrees of masculinization of the external genitalia, but a uterus and ovaries were always seen in the abdominal cavity at laparotomy. Full details of the anatomical findings have already been reported (Clarke, Scaramuzzi \& Short, 1976a).

* Present address: S. S. Cameron Laboratory, Werribee, Victoria 3030, Australia. 


\section{Mating behaviour}

The ewe lambs of the testosterone-implanted mothers were run with the control ewe lambs, and a raddled vasectomized ram of the same breed was introduced into the flock at the onset of their first mating season.

The incidence of oestrus was recorded daily throughout the mating season by the presence of raddle marks on the rump of the ewe. If a ewe showed an indistinct marking she was isolated with a ram to see if she really was oestrous. The day of marking was recorded as Day 0 of the oestrous cycle and the colour of the ram's raddle was changed every 12-14 days. The control, D30-80 and D50-100 ewes were observed during two mating seasons, the D70-120 and D90-140 ewes only during their first season. In addition to showing which ewes were in oestrus, the raddle mark on the rump of an oestrous ewe marked the brisket of any other ewe which mounted her and mounting ewes were thereby identified.

The sheep were divided into two flocks. One flock consisted of D30-80, D50-100 and control ewes and the other of D70-120 and D90-140 ewes so that each flock was made up of sheep of the same age and both flocks contained some sheep experiencing regular oestrous cycles. Numbers were sprayed on the sides of the sheep for observation at a distance and their behaviour was observed from an elevated hide outside the observation paddock ( 0.6 acres).

Two series of observations were carried out, 35 days apart. Before each series all the ewes were given 12 daily i.m. injections of $10 \mathrm{mg}$ progesterone (Intervet) in oil. These injections synchronized oestrus in control ewes and in the androgenized ewes experiencing regular cycles. The two flocks were treated 1 week apart to facilitate study. When the first animal in each flock cameinto oestrus, the flocks were watched for $1 \mathrm{~h}$ after sunrise and $1 \mathrm{~h}$ before sunset each day, to give a total observation period of $5 \mathrm{~h}$.

The sexual behaviour of normal sheep has previously been described by Banks (1964), Bermant, Clegg \& Beamer (1969), Grubb \& Jewell (1973) and Tomkins \& Byrant (1974). For the purposes of the present study the following definitions were used.

Male-like courtship behaviour. 'Scenting'-investigation of the perineal area which may involve licking of the genitalia and the tasting of urine. 'Nudging'-the animal positions itself behind or alongside the ewe facing the same direction, the head is lowered and the neck is twisted while the shoulder is brought in contact with the ewe. This may also be accompanied by rapid licking movements of the tongue and low pitched vocalization. 'Kicking'-the animal orientates as for 'nudging' and raises one foreleg in a stiff forward movement to strike the rear of the ewe. Kicking is commonly displayed in conjunction with nudging. 'Flehmen'-this usually follows scenting. The head is raised to an angle of about $45^{\circ}$, the upper lip is curled backwards and the lower lip is retracted with the jaws opened whilst the animal remains stationary.

Female-like courtship behaviour. 'Urination'-the ewe presents her rear towards the ram and urinates. 'Nudging' - the ewe nudges the ram with her head. 'Tail fanning'- the tail is lifted and wagged rapidly from side to side. 'Head turning'-the ewe's head is turned backwards over her shoulder while she is being courted or mated.

Mounting behaviour. The animal stands on its hind legs to straddle the ewe and may or may not commence pelvic thrusting.

Aggressive behaviour. The head is lowered and a frontal advance, as if to butt, is made towards the head or body of another animal.

\section{Results}

\section{Sexual behaviour during the mating season}

The 8 control ewes had regular oestrous cycles of $16 \cdot 7 \pm 0 \cdot 6$ (S.E.M.) days ( 74 cycles). None of the D30-80 $(\mathrm{N}=6)$ or $\mathrm{D} 50-100(\mathrm{~N}=7)$ ewes showed regular cycles but were sometimes marked by the ram at random intervals. Of the $6 \mathrm{D} 70-120$ ewes, 2 showed regular cycles $(17 \cdot 4 \pm 0.4$ days; 13 cycles), 2 showed oestrus at intervals which were in multiples of 17 days ( 5 cycles) and 2 were marked at random intervals. The $5 \mathrm{D} 90-140$ ewes all showed regular cycles of $16 \cdot 6 \pm 0 \cdot 2$ days ( 45 cycles). 
Table 1. The incidence of mounting behaviour in androgenized ewes, deduced from the presence of raddle marks on their briskets

\begin{tabular}{|c|c|c|c|c|}
\hline \multirow[b]{2}{*}{ Group } & \multirow{2}{*}{$\begin{array}{l}\text { No. of } \\
\text { ewes }\end{array}$} & \multicolumn{3}{|c|}{ No. of ewes marked } \\
\hline & & Thrice & Twice & Once \\
\hline D30-80 & 6 & 0 & 1 & 4 \\
\hline D50-100 & 7 & 6 & 1 & 0 \\
\hline D70-120 & 6 & 5 & 1 & 0 \\
\hline D90-140 & 5 & 0 & 2 & 2 \\
\hline Control & 8 & 0 & 1 & 4 \\
\hline
\end{tabular}

Table 2. Masculine and feminine sexual behaviour dispiayed by androgenized and normal ewes during ten 1-h observations in the field

\begin{tabular}{lccccc}
\hline & \multicolumn{5}{c}{ Group } \\
\cline { 2 - 6 } & D30-80 & D50-100 & D70-120 & D90-140 & Control \\
\hline $\begin{array}{l}\text { No. of ewes } \\
\text { No. of ewes displaying: }\end{array}$ & 6 & 7 & 6 & 5 & 8 \\
$\quad \begin{array}{l}\text { Mounting } \\
\quad \text { No. of mounts/10 h }\end{array}$ & $5^{* *}$ & $7^{* *}$ & $6^{* *}$ & 2 & 0 \\
$\quad \begin{array}{l}\text { \% of mounts with pelvic } \\
\text { thrusting }\end{array}$ & $13^{*}$ & $8^{*}$ & $69^{*}$ & 6 & 0 \\
$\quad$ & 76 & 93 & 65 & 33 & 0 \\
$\quad \begin{array}{l}\text { Nggression } \\
\text { mo. of aggressive }\end{array}$ & 4 & $7^{* *}$ & $6^{* *}$ & 4 & 2 \\
$\begin{array}{l}\text { Male-like courtship } \\
\text { Flehmen }\end{array}$ & $12^{*}$ & $50^{*}$ & $8^{*}$ & $9 *$ & 2 \\
Female-like courtship & 3 & 6 & 5 & 0 & 1 \\
Oestrus & 2 & 6 & 1 & 0 & 0 \\
& 2 & 3 & 2 & 5 & 8 \\
\hline
\end{tabular}

Values significantly different from those of the control ewes; ${ }^{*} P<0.05$ (analysis of variance on data transformed to $\sqrt{ }(\mathrm{x}+1)) ; * * P<0.01$ (Fischer's exact test).

The D50-100 and D70-120 ewes displayed a significantly greater frequency of mounting behaviour than the controls (Table $1, P<0.01$ by the G-test, Sokal $\&$ Rohlf, 1969).

\section{Detailed observations of mating behaviour}

The combined incidence and frequency of behavioural events in each group of ewes during the two 5-h series of observations is shown in Table 2. A smaller proportion of the D30-80, D50-100 and D70-120 ewes displayed oestrus during the detailed observation periods than D90-140 or control ewes. When the androgenized ewes showed oestrus, this was accompanied by female-like courtship behaviour similar to that seen in the controls.

The occurrence of oestrus in the androgenized ewes did not preclude their displaying mounting behaviour. Of the ewes androgenized before Day 90 which came into oestrus, all but one (group D70-120) also showed mounting behaviour.

The number of D30-80, D50-100 and D70-120 ewes mounting was significantly greater than in the controls (Table 2), which were never seen to mount. In the D50-100 and D70-120 animals the frequency of mounting was significantly greater than in all other groups $(P<0.05)$ In general mounting was preceded by male-like courtship behaviour although this was not always so. Flehmen was not seen in any of the D90-140 or control ewes. 
The incidence of aggressive behaviour was higher (Table 2) in all the groups of androgenized ewes than in the controls $(P<0 \cdot 01)$. The intensity of this behaviour was also greater in the D50-100 and D70-120 groups than in the other two androgenized groups. The levels of mounting and aggressive behaviour in the androgenized ewes were positively correlated $(r=0.68 ; P<0.01)$.

\section{Discussion}

As described by Clarke et al. (1976a), the first influence of testosterone on the female fetus is the virilization of her external genitalia. Complete external masculinization was obtained in the D30-80 group, whereas only partial masculinization was evident in the D50-100 and D70-120 lambs, and the D90-140 ewes were essentially normal. We concluded that testosterone-induced sexual differentiation of the genitalia occurred between Days 40 and 50 (Clarke et al., 1976a).

Testosterone affected behaviour at a later stage of development. Ewes which were exposed to testosterone from Days 30,50 or 70 of fetal life usually had infrequent oestrous periods, whereas those implanted after Day 80 (Short, 1974) or Day 90 had normal cycles, suggesting that the ability of testosterone to affect the brain centres responsible for oestrous behaviour was reduced after Day 70 . However, the decreased susceptibility to androgenization in late gestation could also be explained by the increased maternal clearance rate of steroids at this time (Clarke et al., 1976a). The protective effect of rising levels of maternal plasma progesterone in the second half of pregnancy could be another reason for the reduced effectiveness of the testosterone implants after Day 70 (Clarke et al., 1976a). To define precise limits of maximal brain sensitivity to testosterone it will be necessary to implant the hormones directly into the fetus.

Some ewes from each of the androgenized groups also showed masculine behaviour. This was most marked in the D50-100 and D70-120 ewes. Prenatal testosterone was able to enhance masculine behaviour long after the time during which it suppressed oestrus. The D90-140 ewes also showed significantly higher levels of aggression than the control ewes; perhaps this is because aggressive behaviour has a lower threshold for modification by prenatal testosterone than mounting behaviour.

Oestrous behaviour and ovulation are under hypothalamic control in the ewe, although these two phenomena appear to be mediated via different centres; e.g. electroly tic lesions in discrete areas of the hypothalamus may inhibit oestrus but not ovulation (Clegg \& Ganong, 1960; Radford, 1967). The behavioural modifications observed in the androgenized ewes are presumably a result of the action of testosterone or its metabolites at the hypothalamic level; further evidence of this was the failure of ovulation in ewes which had been androgenized before Day 80 of fetal life (Short, 1974; Clarke et al., 1977). Androgenization also affected the ability of the ewes to discharge ovulatory amounts of gonadotrophin in response to oestrogen (Clarke et al. 1976b).

The present results show that prenatal testosterone has a masculinizing effect on a variety of characters in the female, and the interrelationship between these traits can be considered. For example, ewes with a penis (D30-80) displayed less masculine behaviour than ewes with only partly masculinized genitalia (D50-100 and D70-120 groups), demonstrating that the masculine behaviour of the androgenized ewes was independant of their genital virilization.

Another interesting comparison may be made between urination and oestrous behaviour. The oestrous ewe often squats (lordosis) and urinates at the initiation of her courtship display to attract the attention of a ram (Hafez, Cairns, Hulet \& Scott, 1969). When androgenized ewes urinate they do not squat, yet the absence of lordosis does not appear to deter the ram, and rams have often been seen to sniff the penis of completely masculinized (D30-80) ewes and scent the urine (I. J. Clarke, unpublished observations). Neither squatting nor the possession of female external genitalia therefore appear to be necessary for the initiation of courtship by the ram, which may be primarily motivated by urinary pheromones. Rams rendered anosmic became less efficient in detecting oestrous ewes (Lindsay, 1965), indicating the ram's reliance on olfactory cues. When ewes were disguised with covers, rams were still able to detect 'fresh' ewes from 'recently mated' ones (Beamer, Bermant \& Clegg, 1969), again suggesting that rams use their nose more than their eyes during courtship.

Beach has emphasized that androgenization involves two discrete processes-masculinization, 
i.e. the enhancement of male behaviour, and defeminization, i.e. the loss of female behaviour (Beach et al., 1972; Beach, 1975). This dichotomy is certainly borne out by the present study, which clearly shows that androgenized ewes may show male behaviour in the presence or absence of female behaviour and vice versa.

I thank the Farm Staff of the Animal Breeding Research Organization for their co-operation throughout the study. I am grateful to Professor R. V. Short and Dr R. J. Scaramuzzi for their criticism of this manuscript. Receipt of the William Georgetti Scholarship is also acknowledged.

\section{References}

BANKs, E. (1964) Some aspects of sexual behaviour in domestic sheep, Ovis aries. Behaviour 23, 247279.

BEACH, F.A. (1968) Factors involved in the control of mounting behaviour by female mammals. In Perspectives in Reproduction and Sexual Behaviour, pp. 83-131. Ed. M. Diamond. Indiana University Press, Bloomington.

BEACH, F.A. (1975) Hormonal modification of sexually dimorphic behaviour. Psychoneuroendocrinology 1, 3-23.

BEACH, F.A. \& KuEHN, R.E. (1970) Coital behaviour in dogs. X. Effects of androgenic stimulation during development on feminine mating response in females and males. Horm. \& Behav. 1, 347-367.

Beach, F.A., Kuehn, R.E., Sprague, R.H. \& Anisko, J.J. (1972) Coital behaviour in dogs. XI. Effects of androgenic stimulation during development on masculine mating response in females. Horm. \& Behav. 3, 143-168.

Beamer, W., Bermant, G. \& Clegg, M.T. (1969) Copulatory behaviour of the ram, Ovis aries. II. Factors affecting copulatory satiation. Anim. Behav. 17, 706-711.

Bermant, G., Clegg, M.T. \& Beamer, W. (1969) Copulatory behaviour of the ram, Ovis aries. I. A normative study. Anim. Behav. 17, 700-705.

Brown-Grant, K. (1975) A re-examination of the lordosis response in female rats given high doses of testosterone propionate or oestradiol benzoate in the neonatal period. Horm. \& Behav. 6, 351-378.

Clarke, I.J., Scaramuzzi, R.J. \& ShorT, R.V. (1976a) The effects of testosterone implants in pregnant ewes on their female offspring. J. Embryol. exp. Morph. 36, 87-99.
Clarke, I.J., Scaramuzzi, R.J. \& ShORT, R.V. (1976b) Sexual differentiation of the brain: endocrine and behavioural responses of androgenized ewes to oestrogen. J. Endocr. 71, 175-176.

Clarke, I.J., Scaramuzzi, R.J. \& Short, R.V. (1977) Ovulation in prenatally androgenized ewes. $J$. Endocr. (in press).

Clegg, M.T. \& Ganong, W.F. (1960) The effect of hypothalamic lesions on ovarian function in the ewe. Endocrinology 67, 179-186.

GrubB, P. \& Jewell, P.A. (1973) The rut and the occurrence of oestrus in the Soay sheep of St. Kilda. J. Reprod. Fert., Suppl. 9, 491-502.

Hafez, E.S.E., Cairns, R.B., Hulet, C.V. \& ScotT, J.P. (1969) The behaviour of sheep and goats. In The Behaviour of Domestic Animals, pp. 296-348. Ed. E. S. E. Hafez. Williams and Wilkins, Baltimore.

LINDSAY, D.R. (1965) The importance of olfactory stimuli in the mating behaviour of the ram. Anim. Behav. 13, 75-78.

RADFORD, H.M. (1967) Effect of hypothalamic lesions on reproductive activity in sheep. $J$. Endocr. 39, 415422.

SHORT, R.V. (1974) Sexual differentiation of the brain of the sheep. In The Sexual Endocrinology of the Perinatal Period, pp. 121-142. Eds M. G. Forrest \& J. Bertrand. INSERM, Paris.

Sodersten, P. (1973) Increased mounting behaviour in the female rat following a single neonatal injection of testosterone propionate. Horm. \& Behav. 4, 1-17.

Sokal, R.R. \& Rohlf, F.J. (1969) Biometry. W. H. Freeman \& Co., San Francisco.

Tomkins, T. \& BRYANT, M.J. (1974) Oestrous behaviour of the ewe and the influence of treatment with progestogen. J. Reprod. Fert. 41, 121-132.

Received 9 August 1976 